\title{
The Impact of Corporate Charitable Contributions on Audit Hours
}

\author{
Hongmin Chun ${ }^{1}$, Jaeyon $\mathrm{Chu}^{2, *}$ and Yongsuk Yun ${ }^{3}$ \\ 1 School of Business, Chungbuk National University, Chungdae-ro, Seowon-gu, Cheongju-si, \\ Chungcheongbuk-do 28644, Korea; hmchun@cbnu.ac.kr \\ 2 Department of Accounting, Hannam University, 70, Hannam-ro, Daedeok-gu, Daejeon 34430, Korea \\ 3 Business School, Korea University, 145, Anam-ro, Seongbuk-gu, Seoul 02841, Korea; nzzang21@korea.ac.kr \\ * Correspondence: jychu622@hnu.kr; Tel.: +82-10-4916-0715
}

Received: 8 January 2019; Accepted: 13 February 2019; Published: 17 February 2019

\begin{abstract}
Corporate social responsibility (CSR) is a pertinent strategy to enhance consumer perception of product quality and a company's reputation. A growing body of literature has investigated whether corporate charitable contributions play a similar role to that of corporate social responsibility. Controversy still remains over the cause and effect of corporate charitable contributions. This study's objective was to examine whether auditors apply more effort when reviewing firms with a higher level of corporate charitable contributions. For example, if auditors perceive corporate charitable contributions as the opportunistic behavior of managers, then the auditors thoroughly review and prepare financial statements. However, if auditors assess corporate charitable contributions as one of a firm's ethical responsibilities, then they are not likely to put in more effort when reviewing such firms. This paper aims to examine how capital market participants assess a firm's charitable contributions. Using an extensive set of data for Korea from 2008 to 2015, we conducted a battery of robustness analyses to address various endogeneity issues using the abnormal audit hour model, propensity score matching method, and 2SLS regression. We found that corporate charitable contributions were positively associated with audit hours. It indicated that auditors applied more effort when they reviewed firms with corporate charitable contributions. The results suggest that auditors in Korea do not perceive corporate charitable contributions as a CSR activity but rather as an indication of the opportunistic behavior of managers.
\end{abstract}

Keywords: corporate charitable contribution; corporate social responsibilities; legitimization; audit effort

\section{Introduction}

Corporate social responsibility (CSR) is a pertinent strategy to enhance consumer perception of product quality and a company's reputation [1] and to lower the cost of capital [2,3]. Among various dimensions of CSR, researchers have recently focused on corporate charitable contributions as a direct measure of CSR $[4,5]$. A growing body of literature has investigated why firms engage in charitable contributions and how this affects the firms' future financial performance.

In this study, we examined whether corporate charitable contributions influenced auditors' perceptions of firm risk. If corporate charitable contributions are attributed to the opportunistic behavior of managers, then auditors concentrate more time on thoroughly reviewing and preparing financial statements. However, if they assess corporate charitable contributions as one of a firm's ethical responsibilities, then they are not likely to put in more effort when reviewing such firms. Despite the growing importance of corporate charitable contributions, there are few studies examining how capital market participants assess firms' charitable contributions. This study aims to fill the void by examining auditors' responses to firms' charitable contribution choices using audit hours. 
Firms make corporate charitable contributions due to their slack resources [6], firm size [7], ownership structure [8], managers' altruism [9], reputational capital view [4], and business awards [5]. There are various competing arguments related to the impact of corporations' decisions regarding charitable contribution. Altruistic theory insists that corporate giving will enhance a firm's information environment and reputation, therefore reducing firm risk. On the other hand, agency theory argues that managers opportunistically abuse philanthropy to maximize their own wealth, which could increase a firm's level of risk and deteriorate its future performance. In a similar vein, legitimacy theory also insists that managers will make charitable contributions intentionally to offset bad news. For instance, the Chairman of Hyundai Motors, the second largest company on the Korean stock market, announced an aggressive donation plan after the Chairman faced a guilty verdict. Following this logic, charitable contributions are highly connected to agency theory or legitimacy theory and induce auditors to exert more effort or audit planning to lower the audit risk to an acceptable level.

There is also some skepticism about CSR reporting in the popular press [10] because firms engage in CSR activities to cover their opportunistic behavior [11,12]. On this issue, the neo-classical economist Milton Friedman suggests that CSR does not align with the managers' primary objective of maximizing shareholder value. Some researchers suggest that firms should not incorporate CSR into their strategic decisions, because CSR does not affect shareholder value, and at worst, it destroys such value [13,14]. They argue that managers, as agents appointed by shareholders to manage the firm, work toward their personal social agendas rather than shareholders' interests $[15,16]$. This tendency is more pronounced in developing countries because most CSR activities are driven by an owner-manager's decision following the manager's agency theory.

We extend the scope of prior studies by focusing on Korean firms. There is no comprehensive firm/year audit hours data available for the U.S. or U.K. However, since the Korean government requires firms to disclose individual firm/year audit hours to the public, we were able to acquire vast amounts of audit hour data as a proxy for auditors' audit effort. Therefore, Korea is a good research setting for examining the association between corporate charitable contributions and an auditor's perception of corporate charitable contributions (audit hours). Additionally, Korean firms report their charitable contributions in their audited financial statements [5]. Thus, we also had access to high-quality corporate giving data, which enabled us to obtain a large sample of donation expenses in Korea.

Using an extensive set of data for Korea from 2008 to 2015, we obtained several interesting results. First, we found that a higher level of corporate charitable contributions is positively related to more audit hours, suggesting that engaged auditors perceive firms with more corporate charitable contributions as being exposed to higher risks. We conducted a battery of robustness analyses to address various endogeneity issues using the abnormal audit hour model, propensity score matching method, and 2SLS regression. Our main results remain qualitatively unchanged. Therefore, our findings suggest that corporate charitable contributions in Korea are more likely to be driven by the opportunistic behavior of managers.

This paper makes several contributions to the literature. First, few studies investigate the relation between corporate charitable contributions and audit hours due to the lack of audit hour data in the U.S. However, we were able to obtain vast amounts of audit hour data as a proxy for auditors' audit effort and high-quality corporate giving data, therefore this study may be the first attempt to examine the direct association between corporate charitable contribution and audit effort using qualified audit hour data in Korea. Second, Korean corporate charitable contributions differ from those in other countries. Unlike other developed countries, such as the U.S. and the U.K., Korea has a different perception of corporate charitable contributions. Even though Korean firms have increasingly paid attention to CSR, especially with a high level of corporate philanthropy, Korean firms are criticized for engaging in corporate philanthropy to restore their reputation that has been damaged or to secure favor under government policy. Moreover, the mainstream literature about CSR reports on the context of developed countries, such as the U.S. or U.K., leaving the empirical question of whether such results 
apply to other countries. More specifically, the economic consequences of CSR may vary according to a country's information environment and legal origin [17], so it is important to investigate CSR's role and economic consequences in emerging countries such as Korea. In this study, we aim to extend the scope of the prior literature by examining charitable contributions and their economic consequences in emerging countries. Third, our study has some practical implications for auditors. When auditors are engaged to firms with high corporate charitable contributions, they carefully check their audit firms to reduce the audit risk to their acceptable level. Notwithstanding the results, our findings on corporate charitable contributions in Korea may be useful to other countries, which have political, economic, legal, and ethical institutions that differ from developed countries.

The remainder of our paper proceeds as follows. Section 2 briefly reviews prior studies and develops the hypotheses. Section 3 describes our research method and sample. Section 4 presents our empirical findings. Finally, Section 5 presents our conclusions.

\section{Prior Literature and Hypotheses Development}

\subsection{Prior Literature}

CSR is a corporation's commitment to act ethically. It encompasses various attributes of corporate activities, such as environmental efforts, ethical labor practices, and philanthropy. CSR aims to improve society overall by enhancing the quality of life for both employers and society itself. Proponents assert that CSR enhances shareholder wealth, information transparency, and easier access to the capital market [18-20]. Accordingly, it reduces information asymmetry between firms and investors, thereby mitigating firm risk [21]. However, some argue that CSR initiatives could be a waste of firms' resources. For example, Friedman (1970) [13] argues that CSR is one of the agency problems where managers misallocate firms' resources or shareholder wealth to pursue their social mission. Barnett and Salomon $(2006,2012)[22,23]$ find that CSR activities may not benefit firms in the short term, or even in the long term.

Corporate charitable contributions have been identified as an attribute of CSR activities. There are three views about corporate charitable contributions in the literature [24]. According to altruistic motivation, corporate philanthropic behavior is attributable to a firm's ethical responsibilities [9,24-26]. Campbell and Slack (2007) [27] assert that firms choose charitable giving to achieve the dual objective of charitable benevolence and corporate value creation.

On the other hand, agency theory suggests that managers use charitable giving opportunistically to maximize their own benefits [28,29]. For example, managers can enhance their personal reputation and social networks by supporting their own charity preferences with corporate giving. Masulis and Reza (2015) [28] report that $62 \%$ of firms give contributions to CEO-affiliated charities.

Lastly, legitimacy theory suggests that managers use corporate charitable contributions as a means of legitimization. To mitigate or hide poor performance, firms choose charitable contributions intentionally. Specifically, firms can make charitable contributions to build political capital in order to avoid unwanted political interference or unfavorable government regulations [30]. Ashford and Gibbs (1990) [31] and Dowling and Pfeffer (1975) [32] find that firms undertake charitable giving to project a positive image of social performance in order to offset or mitigate poor performance. In addition, Chen et al. (2008) [33] find that worse performers are more likely to make charitable contributions. In summary, corporate philanthropy may be more a tool of legitimization than a measure of corporate social responsibility.

\subsection{Hypotheses Development}

As we discuss above, corporate charitable contributions have been an integral part of CSR. However, it is unclear why firms engage in charitable contributions and how this will affect the firms' future financial performance. Under altruistic theory, corporate charitable contributions are undertaken to improve a company's financial performance. Lev et al. (2010) [34] find that an increase 
in corporate charitable contributions is associated with subsequent revenue growth. To the extent that engagement in corporate charitable contributions is positively associated with a firm's financial performance, corporate charitable contributions reduce firm risk. On the other hand, agency theory and legitimacy theory insist that managers intentionally choose charitable contributions for their own sake or to offset poor social performance. In this case, charitable contributions represent a negative signal and increase firm risk.

To summarize, corporate charitable contributions could be both a good signal and bad signal to capital market participants. In such cases, it is unclear how sophisticated market participants such as auditors perceive or respond to corporate charitable contributions. Because auditors are responsible for providing credible accounting information to the capital markets, they devote their efforts to reduce firm/audit risk $[35,36]$. If charitable contributions indicate a positive CSR, then auditors perceive those firms as having a lower risk. Then, there is no reason for auditors to exert more effort when they cover firms with higher corporate charitable contributions. However, if charitable contributions are related to agency theory and legitimacy theory, then auditors regard those firms as having a higher risk. Therefore, they are more likely to spend more time auditing those firms in order to increase audit quality [37].

The Korean government strengthened auditors' legal liability to protect minority shareholders after passing the new Securities Law in 2000. Thus, auditors may perceive a higher threat of reputational damage and litigation costs from the extent of corporate charitable contributions according to agency theory and legitimacy theory. Under these circumstances, auditors evaluate corporate charitable contributions as increasing audit risk. Thus, auditors put more time and effort into mitigating audit risk stemming from corporate charitable contributions.

Audit hours are more factual than audit fees to accurately capture auditors' efforts because non-audit services, auditor independence, or audit fee agreements at the initial audit engagement can affect audit fees $[38,39]$. Therefore, we posit that ambiguity and uncertainty concerning corporate charitable contributions will induce auditors to put in more effort, such as by increasing their audit hours. Based on this discussion, the hypothesis is as follows:

Hypothesis 1. Corporate charitable contributions are associated with audit hours.

\section{Research Methodology}

\subsection{Model Specification}

We estimated the following regression model to analyze whether auditors exert more effort when they audit firms with higher charitable contributions. In Equation (1), our main variables of interest are DOV and DOVRED. When auditors perceive corporate charitable contributions as the opportunistic behavior of managers, they spend more hours to review those firms. Then, we will observe positive coefficient estimates for DOV and DOVRED.

$$
\begin{gathered}
\text { LAHt }=\beta 0+\beta 1 \text { DOVRED }(\text { DOV }) t+\beta 2 \text { LNSIZEt }+\beta 3 \text { INVERC }+\beta 4 \text { LIQt }+\beta 5 \text { ROAt }+\beta 6 \text { LOSSt } \\
+\beta 7 \text { FIRSTt }+\beta 8 \text { LEVt }+ \text { YEAR Dummies }+\varepsilon,
\end{gathered}
$$

where:

Dependent Variable

LAH: Natural logarithm of audit hours.

Key Variables

DOV: Logarithm of donation expenses.

DOVRED: Residual value of regression between the dependent variable,

DOV, and explanatory variables, LNSIZE, LEV, ROA, and LOSS. 
Control Variables

LNSIZE: Natural logarithm of total assets.

INVERC: Inventory plus receivables divided by total assets.

LIQ: Current assets divided by current liabilities.

ROA: Return on Assets.

LOSS: Indicator variables of loss.

FIRST: A dummy variable equal to 1 if an audit is a first-year audit, and 0 otherwise.

LEV: Leverage; Liabilities scaled by total assets.

Year Dummies: Year dummy variables.

We also controlled various proxies known to affect the auditor's audit efforts. The most influential factor determining audit effort is firm size, one of the important and fundamental firm characteristics. We therefore controlled the firm size, measuring it as a natural logarithm of total assets following prior literature $[5,7,15-17,20,37-41]$. We used control variables similar to those used in prior studies. Detailed variable definitions can be seen in Appendix A. We included year dummy variables to control for differences in audit hours year-by-year. Because we used a firm-level clustering regression in the study, it was not necessary to control industry dummies. Moreover, we obtained similar results when we added industry dummies.

\subsection{Sample}

We based our empirical analysis on listed firms in Korea from 2008 to 2015. We extracted accounting and audit hour data from the TS2000 database. As at December of each year, we selected companies that satisfied the following criteria: (1) the company had financial statement data, which we required to compute the main variables, available from TS2000; (2) all proxies were available; and (3) the company was a non-financial firm. Our final sample included 10,953 firm-year observations.

\section{Empirical Results}

\subsection{Descriptive Statistics}

Panel A of Table 1 shows the annual distribution of the sample. Although there are some deviations in the number of samples per year, the annual distribution is balanced overall. Panel B of Table 1 provides descriptive statistics for the variables. The mean log of audit hours (LAH) is 6.785 and the mean value of abnormal audit hours is zero. The average logarithm number of donation expenses (DOV) is 10.668 , and the median value is 10.461 . About $22.3 \%$ of the sample firms report losses and the average leverage ratio is 0.408 . The mean value of FIRST is 0.326 , indicating that approximately $33 \%$ of the sample firms have first-year engaged audit firms. The descriptive statistics of other control variables are similar to prior audit hour studies in Korea [40].

Table 1. Descriptive statistics.

\begin{tabular}{ccc}
\hline \multicolumn{3}{c}{ Panel A. Distribution by Year } \\
\hline Year & Number of Observations (N. Obs.) & $\begin{array}{c}\text { Cumulative } \\
\text { Percent (\%) }\end{array}$ \\
\hline 2008 & 1585 & 14.47 \\
2009 & 1614 & 29.21 \\
2010 & 1696 & 44.69 \\
2011 & 1140 & 55.1 \\
2012 & 1190 & 65.96 \\
2013 & 1208 & 76.99 \\
2014 & 1230 & 88.22 \\
2015 & 1290 & 100 \\
\hline Total & 10,953 & 100 \\
\hline
\end{tabular}


Table 1. Cont.

\begin{tabular}{ccccccccc}
\hline \multicolumn{10}{c}{ Panel B. Descriptive Statistics } \\
\hline & N. Obs. & MEAN & STD & MIN & $\mathbf{1 0 \%}$ & Median & $\mathbf{9 0 \%}$ & MAX \\
\hline LAH & 10,953 & 6.785 & 0.837 & 2.773 & 6.011 & 6.717 & 7.824 & 9.181 \\
ABLAH & 10,953 & 0.000 & 0.607 & -4.724 & -0.537 & 0.0683 & 0.592 & 2.186 \\
DOV & 10,953 & 10.668 & 2.587 & 4.605 & 7.438 & 10.461 & 14.263 & 17.234 \\
DOVRED & 10,953 & 0.000 & 0.002 & -0.002 & -0.001 & -0.001 & 0.001 & 0.012 \\
LNSIZE & 10,953 & 26.061 & 1.431 & 23.503 & 24.529 & 25.773 & 28.062 & 30.557 \\
INVERC & 10,953 & 0.271 & 0.155 & 0.000 & 0.077 & 0.258 & 0.484 & 0.701 \\
LIQ & 10,953 & 2.392 & 2.745 & 0.238 & 0.679 & 1.494 & 4.837 & 17.130 \\
ROA & 10,953 & 0.023 & 0.092 & -0.416 & -0.069 & 0.033 & 0.112 & 0.212 \\
LOSS & 10,953 & 0.223 & 0.416 & 0.000 & 0.000 & 0.000 & 1.000 & 1.000 \\
FIRST & 10,953 & 0.326 & 0.469 & 0.000 & 0.000 & 0.000 & 1.000 & 1.000 \\
LEV & 10,953 & 0.408 & 0.196 & 0.048 & 0.147 & 0.404 & 0.661 & 0.881 \\
TURN & 10,953 & 0.902 & 0.515 & 0.063 & 0.361 & 0.811 & 1.533 & 2.928 \\
ADINT & 10,953 & 0.010 & 0.024 & 0.000 & 0.000 & 0.001 & 0.030 & 0.167 \\
\hline
\end{tabular}

Note. LAH: Log of audit hours. ABLAH: Abnormal audit hours as audit hours minus the normal level of audit hours. We estimated the predicted value of $\mathrm{LAH}$, and then calculated the abnormal audit hours by taking the difference between actual and normal audit hours. We used ABLAH as the supplementary variable for the LAH. DOV: Log of donation expenses. DOVRED is the residual value of the regression between the dependent variable, DOV, and the explanatory variables, LNSIZE, LEV, ROA, and LOSS variables. We used it as our main proxy for corporate charitable contribution. The "Residual Charitable Contribution" is uncorrelated with firm size, leverage, profitability, and LOSS. Therefore, we used "(DOVRED) Residual Charitable Contribution" as our main variable. LNSIZE: Natural log of total assets. INVERC: Inventory and accounts receivables ratio. LIQ: Current ratio. ROA: Return on assets. LOSS is an indicator variable equal to 1 if the firm's net income is negative and 0 otherwise. FIRST: A dummy variable equal to 1 if an audit is a first-year audit, and zero otherwise. LEV: Debt ratio. TURN: Turnover ratio. ADINT: Advertising intensity, calculated by advertising cost divided by total equity.

\subsection{Univariate Analyses}

Table 2 shows the correlation matrix. The logarithm value of donation expenses (DOV) is positively correlated with the log of audit hours (LAH) significantly $(0.482,5 \%$ significance level). The residual value of donation expenses (DOVRED) is also significantly correlated with the log of audit hours, but at a lower magnitude (0.024, 5\% significance), suggesting that the association between donation expenses and audit hours in the univariate analysis supports our first hypothesis that corporate charitable contributions are positively associated with audit hours. From the correlation analysis, we found that firms with higher corporate charitable contributions increased auditors' audit effort. The correlation analysis does not capture the real effects of the association between the residual value of donation expenses and audit hours. We therefore performed multivariate regression analyses to examine the overall association between the residual value of donation expenses and audit hours with control variables, as presented in the next section.

Table 2. Correlation matrix.

\begin{tabular}{|c|c|c|c|c|c|c|c|c|c|c|}
\hline Variable & LAH & DOV & DOVRED & LNSIZE & INVERC & LIQ & ROA & LOSS & FIRST & LEV \\
\hline DOV & 0.482 & & & & & & & & & \\
\hline DOVRED & 0.024 & 0.467 & & & & & & & & \\
\hline LNSIZE & 0.685 & 0.669 & 0.000 & & & & & & & \\
\hline INVERC & -0.123 & -0.104 & -0.008 & -0.163 & & & & & & \\
\hline LIQ & -0.175 & -0.137 & -0.036 & -0.215 & -0.164 & & & & & \\
\hline ROA & 0.031 & 0.214 & 0.000 & 0.126 & -0.004 & 0.144 & & & & \\
\hline LOSS & -0.016 & -0.193 & 0.000 & -0.117 & -0.017 & -0.090 & -0.712 & & & \\
\hline FIRST & -0.070 & 0.021 & 0.019 & 0.045 & -0.031 & -0.010 & 0.013 & -0.010 & & \\
\hline LEV & 0.175 & 0.071 & 0.000 & 0.233 & 0.253 & -0.605 & -0.360 & 0.275 & 0.039 & \\
\hline TURN & 0.026 & 0.052 & 0.063 & -0.019 & 0.474 & -0.220 & 0.136 & -0.134 & 0.002 & 0.241 \\
\hline
\end{tabular}

Note. This table presents Pearson correlations between key variables for the pooled sample. Please see the note on Table 1 for the explanation of the variables. The bold number indicates the significance level at $5 \%$ or better (two-tailed). 


\subsection{Multivariate Analyses}

Table 3 shows the multivariate regression results for corporate charitable contributions and audit hours. In the first column of Table 3, corporate charitable contributions are significantly positively associated with audit hours, and the coefficient of DOVRED is 9.284 (1\% significance) in the pooled sample. The result suggests that engaged auditors exert more effort when their clients have a high level of donation expense. It indicates that auditors perceive a firm's discretionary donation expenses as an audit risk. Our findings are robust when we apply year-fixed effects and adjust standard errors for firm-level clustering to correct for serial correlation within a firm (column 2). In column 3, we use the actual value of donation expense (DOV) instead of the residual value of donation expense (DOVRED). We found that corporate charitable contributions had a significantly positive coefficient with audit hours. In summary, these empirical results support our hypothesis that a higher level of charitable contributions is associated with higher auditor input levels in Korea. That is, auditors spend more audit hours related to charitable contributions, which is closely related to the opportunistic behavior of managers in Korea.

Table 3. Regression results for corporate charitable contribution and audit hours.

\begin{tabular}{|c|c|c|c|}
\hline & (1) & (2) & (3) \\
\hline VARIABLES & $\begin{array}{c}L A H \\
\text { Pooled OLS }\end{array}$ & $L A H$ & $L A H$ \\
\hline DOVRED & $\begin{array}{c}9.284^{* * *} \\
{[2.868]}\end{array}$ & $\begin{array}{c}12.953^{* *} \\
{[2.022]}\end{array}$ & \\
\hline DOV & & & $\begin{array}{c}0.017 * * * \\
{[3.061]}\end{array}$ \\
\hline LNSIZE & $\begin{array}{l}0.408^{* * *} \\
{[92.388]}\end{array}$ & $\begin{array}{l}0.406^{* * *} \\
{[40.019]}\end{array}$ & $\begin{array}{l}0.386^{* * *} \\
{[34.946]}\end{array}$ \\
\hline INVERC & $\begin{array}{c}-0.221 * * * \\
{[-5.063]}\end{array}$ & $\begin{array}{l}-0.201 * * \\
{[-1.988]}\end{array}$ & $\begin{array}{l}-0.204^{* *} \\
{[-2.020]}\end{array}$ \\
\hline LIQ & $\begin{array}{c}-0.008^{* * *} \\
{[-3.174]}\end{array}$ & $\begin{array}{c}-0.009 \\
{[-1.007]}\end{array}$ & $\begin{array}{c}-0.009 \\
{[-0.966]}\end{array}$ \\
\hline ROA & $\begin{array}{c}-0.304 * * * \\
{[-3.244]}\end{array}$ & $\begin{array}{c}-0.156 \\
{[-0.728]}\end{array}$ & $\begin{array}{c}-0.194 \\
{[-0.918]}\end{array}$ \\
\hline LOSS & $\begin{array}{c}0.114 * * * \\
{[5.814]}\end{array}$ & $\begin{array}{c}0.123 * * * \\
{[3.720]}\end{array}$ & $\begin{array}{c}0.127 * * * \\
{[3.833]}\end{array}$ \\
\hline FIRST & $\begin{array}{l}-0.181^{* * *} \\
{[-14.780]}\end{array}$ & $\begin{array}{l}-0.089 * \\
{[-2.061]}\end{array}$ & $\begin{array}{l}-0.088^{* *} \\
{[-2.032]}\end{array}$ \\
\hline LEV & $\begin{array}{c}-0.149^{* * *} \\
{[-3.538]}\end{array}$ & $\begin{array}{l}-0.102 \\
{[-0.939]}\end{array}$ & $\begin{array}{l}-0.087 \\
{[-0.806]}\end{array}$ \\
\hline TURN & $\begin{array}{c}0.117^{* * *} \\
{[8.863]}\end{array}$ & $\begin{array}{c}0.122 * * * \\
{[3.883]}\end{array}$ & $\begin{array}{c}0.120 * * * \\
{[3.786]}\end{array}$ \\
\hline Constant & $\begin{array}{l}-3.761^{* * *} \\
{[-32.289]}\end{array}$ & $\begin{array}{l}-3.899 * * * \\
{[-15.181]}\end{array}$ & $\begin{array}{l}-3.554 * * * \\
{[-13.734]}\end{array}$ \\
\hline Year Dummy & & Yes & Yes \\
\hline Cluster by Firm & & Yes & Yes \\
\hline Observations & 10,953 & 10,953 & 10,953 \\
\hline R-squared & 0.488 & 0.515 & 0.516 \\
\hline
\end{tabular}

Note. See the notes on Tables 1 and 2 for the definitions of the variables. t-statistics, reported in parentheses, are adjusted for firm-level clustering to correct for serial correlation within a cluster (a firm). ${ }^{* * *}, * *$, and ${ }^{*}$ indicate significance at the $1 \%, 5 \%$, and $10 \%$ levels or better, respectively. The regression equations are as follows.

\subsection{Robustness Tests}

For robustness, we first used alternative measures for audit efforts, abnormal audit hours, to reduce potential endogeneity [41]. We calculated abnormal audit hours as follows. In the first stage, we estimated a normal level of audit hours using a conventional model of audit hours, and then obtained abnormal audit hours by taking the difference between the actual and normal audit hours. Therefore, a higher level of abnormal audit hours (ABLAH) indicates the additional effort level of engaged auditors beyond the normal level. We thus used this ABLAH as our supplementary measure of audit effort. Table 4 presents the robustness results using abnormal audit hours (ABLAH) as a proxy for audit effort, and our previous findings remain unchanged. 
Table 4. Robustness tests: regression results for corporate charitable contribution and abnormal audit hours and propensity score matched analysis.

\begin{tabular}{ccc}
\hline & $\mathbf{( 1 )}$ & $\mathbf{( 1 )}$ \\
\hline VARIABLES & ABLAH & LAH \\
& & PSM \\
\hline DOVRED & $12.953^{* *}$ & $14.852^{* *}$ \\
& {$[2.022]$} & {$[2.292]$} \\
LNSIZE & -0.001 & $0.262^{* * *}$ \\
& {$[-0.088]$} & {$[14.560]$} \\
INVERC & $-0.201^{* *}$ & -0.116 \\
& {$[-1.988]$} & {$[-1.064]$} \\
LIQ & -0.009 & -0.011 \\
& {$[-1.007]$} & {$[-1.155]$} \\
ROA & 0.057 & $-0.425^{* *}$ \\
& {$[0.267]$} & {$[-2.528]$} \\
LOSS & 0.019 & $0.062^{* *}$ \\
& {$[0.576]$} & {$[1.995]$} \\
FIRST & $-0.089^{* *}$ & -0.056 \\
& {$[-2.061]$} & {$[-1.084]$} \\
LEV & -0.060 & -0.042 \\
& {$[-0.553]$} & {$[-0.330]$} \\
TURN & $0.122 * * *$ & $0.089^{* *}$ \\
& {$[3.883]$} & {$[2.504]$} \\
Constant & -0.077 & -0.256 \\
& {$[-0.301]$} & {$[-0.563]$} \\
Year Dummy & Yes & Yes \\
Cluster by Firm & Yes & Yes \\
Observations & 10,953 & 6934 \\
R-squared & 0.080 & 0.205 \\
\hline
\end{tabular}

Note. See the notes on Tables 1 and 2 for the definitions of the variables. t-statistics, reported in parenthesis, are adjusted for firm-level clustering to correct for serial correlation within a cluster (a firm). ${ }^{* * * * * *}$, and ${ }^{*}$ indicate significance at the $1 \%, 5 \%$, and $10 \%$ levels or better, respectively.

Furthermore, we constructed a matched sample based on the propensity score matching methodology using a Big 4 auditor selection model. There is a debate about endogeneity issues related to the difference between Big 4 and Non-Big 4 auditors. Researchers argue that the difference stems from inherent factors such as client firm characteristics, which therefore leads to biased results [42]. To address this concern, we constructed an alternative sample using the propensity score matching methodology instead of using the whole sample, then we re-examined the analyses. Following Lawrence et al. (2011) [42], we constructed a matched sample using the same variables in the main regression with sample firms based on one-to-one matching with non-replacement and a 0.03 caliper level. We report the results in Table 4, which are similarly unchanged.

Our empirical findings are robust using an OLS regression and propensity score matching methodology. However, it is possible that higher audit hours lead firms to increase their corporate charitable contributions. This concern stems from the fact that firms with high audit hours tend to be larger, thus resulting in higher corporate charitable contributions. Li (2016) [43] suggests that Generalized Method of Moments (GMM) has the greatest correction effect on the coefficient, followed by instrumental variables, fixed effects models, lagged variable, and control variables. We therefore needed further analysis to alleviate this reverse causality problem, which required a two-stage least-squares regression to reduce this endogeneity problem. To conduct the 2SLS regression, we had to determine the instrument variable correlated with our independent variable, corporate charitable contributions. To control this endogeneity problem, we used a consumer awareness variable, advertising intensity, presented by Servaes and Tamayo (2013) [44]. They suggest that advertising intensity may affect consumers' perception of a firm's CSR activity. Higher advertising intensity increases corporate charitable contributions, which suggests that the reputational capital effect is more effective when consumers' recognition of CSR activity is high. Following Servaes and Tamayo (2013) [44], we used advertising intensity as an instrument variable for the first-stage regression model, and then calculated the fitted value of corporate charitable contributions (Predicted DOV). As we 
expected, column 1 of Table 5 shows that advertising intensity (ADINT) is positively associated with corporate charitable contributions at a $1 \%$ level of significance. In the second stage, we re-regressed the fitted value of corporate charitable contributions with audit hours. The results of the 2SLS regression suggest that even the fitted value of corporate charitable contributions is positively associated with audit hours.

Table 5. Robustness tests: 2SLS regression.

\begin{tabular}{|c|c|c|}
\hline & (1) & (2) \\
\hline VARIABLES & $\begin{array}{l}\text { DOVRED } \\
\text { First Stage }\end{array}$ & $\begin{array}{c}\text { LAH } \\
\text { Second Stage }\end{array}$ \\
\hline ADINT & $\begin{array}{c}0.012 * * * \\
{[7.811]}\end{array}$ & \\
\hline PREDICTED DOV & & $\begin{array}{c}0.092^{* * *} \\
{[3.651]}\end{array}$ \\
\hline LNSIZE & $\begin{array}{c}0.000 \\
{[-0.657]}\end{array}$ & $\begin{array}{c}0.296^{* * *} \\
{[9.296]}\end{array}$ \\
\hline INVRC & $\begin{array}{l}-0.001 * * \\
{[-2.200]}\end{array}$ & $\begin{array}{l}-0.188^{*} \\
{[-1.870]}\end{array}$ \\
\hline LIQ & $\begin{array}{l}-0.000^{* *} \\
{[-2.542]}\end{array}$ & $\begin{array}{c}-0.005 \\
{[-0.579]}\end{array}$ \\
\hline ROA & $\begin{array}{c}0.000 \\
{[-0.501]}\end{array}$ & $\begin{array}{c}-0.34 \\
{[-1.630]}\end{array}$ \\
\hline LOSS & $\begin{array}{c}0.000 \\
{[0.388]}\end{array}$ & $\begin{array}{c}0.144^{* * *} \\
{[4.149]}\end{array}$ \\
\hline FIRST & $\begin{array}{c}0.000 \\
{[-0.257]}\end{array}$ & $\begin{array}{l}-0.081 \text { * } \\
{[-1.922]}\end{array}$ \\
\hline LEV & $\begin{array}{l}-0.000 * \\
{[-1.949]}\end{array}$ & $\begin{array}{c}0.005 \\
{[0.046]}\end{array}$ \\
\hline TURN & $\begin{array}{c}0.000^{* * *} \\
{[3.338]}\end{array}$ & $\begin{array}{c}0.095^{* * *} \\
{[3.078]}\end{array}$ \\
\hline Constant & $\begin{array}{c}0.001 \\
{[1.010]}\end{array}$ & $\begin{array}{c}-2.041^{* * *} \\
{[-3.584]}\end{array}$ \\
\hline Year Dummy & Yes & Yes \\
\hline Cluster by Firm & Yes & Yes \\
\hline Observations & 10,953 & 10,953 \\
\hline R-squared & 0.04 & 0.517 \\
\hline
\end{tabular}

Note. Predicted DOV is the fitted value of the first-stage regression. This table shows the 2SLS regression results. See the notes on Tables 1 and 2 for the definitions of the variables. t-statistics, reported in parentheses, are adjusted for firm-level clustering to correct for serial correlation within a cluster (a firm). ${ }^{* * *},{ }^{* *}$, and ${ }^{*}$ indicate significance at the $1 \%, 5 \%$, and $10 \%$ levels or better, respectively.

Based on the robustness test, we conclude that corporate charitable contributions raise the level of audit effort in Korea. Auditors perceive corporate charitable contributions as an audit risk factor, for which they spend more audit hours.

\section{Conclusions}

This study examines the relation between firms' corporate charitable contributions and audit efforts using Korean data. We found that a higher level of corporate charitable contributions was significantly associated with higher levels of audit hours, suggesting that engaged auditors spend more time auditing firms with higher corporate charitable contributions. As auditors are responsible for providing credible accounting information to the capital markets, they devote more effort when they audit firms with higher corporate charitable contributions in order to increase audit quality. Our result supports agency theory and legitimacy theory regarding corporate charitable contributions.

Nonetheless, there may be possible omitted variables related to corporate charitable contributions that bias our empirical result, in addition to some possible factors that could influence the firms' audit hours. We therefore tried to minimize the problem of omitted variables by following prior literature. To tackle and reduce this concern, and to show that our association was valid, we conducted a battery of robustness tests, including abnormal audit hours, propensity score matching, and 2SLS regression. Our findings indicate that auditors put in more effort to reduce their clients' audit risks. Above all, our 
findings suggest that a firm's social sustainable activity, specifically corporate charitable contributions made by the firm, is not driven by motives related to CSR activities in Korea, but is rather related to the opportunistic behavior of managers. Therefore, the auditor's prerequisite is to stimulate the sustainability and positive effect of corporate charitable contributions.

This paper makes several contributions to the literature. First, few studies investigate the relationship between corporate charitable contributions and audit hours due to the lack of audit hour data in the U.S. Therefore, this study may be the first attempt to examine the direct association between corporate charitable contribution and audit effort using qualified audit hour data in Korea. Second, the mainstream literature about CSR reports on the context of developed countries, such as the U.S. or U.K., leaving the empirical question of whether such results apply to other countries. More specifically, the economic consequences of CSR may vary according to a country's information environment and legal origin, so it is important to investigate CSR's role and economic consequences in emerging countries such as Korea. Third, our study has some practical implications for auditors. When auditors are engaged to firms with high corporate charitable contributions, they carefully check their audit firms to reduce the audit risk to their acceptable level. Notwithstanding the results, our findings on corporate charitable contributions in Korea may be useful to other countries, which have political, economic, legal, and ethical institutions that differ from developed countries.

Furthermore, several interesting questions remain. First, it would be interesting to explore the role of corporate governance in the perception of corporate charitable contributions. For example, market competition [45], CEO tournament [46], compensation incentives [47], and analysts' following [48] could play a corporate governance role in charitable contributions. In the case of firms adopting those various governance mechanisms, we could examine whether corporate governance mitigates the negative perception of corporate charitable contributions. In addition, internal or external governance mechanisms may mitigate or exacerbate the association between corporate charitable contributions and audit hours. Therefore, we could explore whether auditors' negative perceptions of corporate charitable contributions could be varied according to the corporate governance schemes. Second, it would be meaningful to broaden our research topic to an international context. Different results may be obtained under a different information environment or legal status.

Author Contributions: H.C. and J.C. contributed to designing the theoretical framework and undertaking the primary research. Y.Y. was in charge of the research method and the statistical analysis. H.C., J.C., and Y.Y. discussed the results and were responsible for writing the manuscript. Formal analysis, Y.Y.; Funding acquisition, J.C.; Methodology, Y.Y.; Supervision, H.C.; Writing-original draft, H.C. and J.C; Writing-review and editing, H.C., J.C., and Y.Y.

Funding: This work was supported by 2018 Hannam University Research Fund.

Conflicts of Interest: The authors declare no conflict of interest.

\section{Appendix A. Variable Definitions}

\begin{tabular}{ll}
\hline Variable & Definition \\
\hline $\begin{array}{l}\text { Dependent Variables } \\
\text { LAH }\end{array}$ & $\begin{array}{l}\text { A proxy for the external auditor's audit efforts. } \\
\text { ABLAH } \\
\text { Independent Variables }\end{array}$ \\
The additional variable for LAH, calculated by actual audit hours minus the normal level of audit hours. \\
DOVRED & Logarithm of donation expenses. \\
LNSIZE & The residual value of the regression between the $L A H, D O V, L N S I Z E, L E V, R O A$, and $L O S S$. \\
INVERC & Natural logarithm of total assets. \\
LIQ & Inventory and receivable ratio, calculated by the sum of inventory and receivables divided by total assets. \\
ROA & Quick ratio (short-term solvency ratio), calculated by current assets divided by current liabilities. \\
LOSS & Return on assets, measured as net income divided by beginning total assets. \\
FIRST & Indicator variable for firms reporting losses. \\
LEV & A dummy variable equal to 1 if an audit is a first-year audit, and 0 otherwise. \\
\hline
\end{tabular}




\section{References}

1. Milgron, P.; Roberts, J. Price and advertising signals of product quality. J. Political Econ. 1986, 94, 796-821. [CrossRef]

2. Beatty, R.; Ritter, J. Investment banking, reputation, and the underpricing of initial public offerings. J. Financ. Econ. 1986, 15, 213-232. [CrossRef]

3. El Ghoul, S.; Guedhami, O.; Kwok, C.Y.; Mishra, D. Does corporate social responsibility affect the cost of capital? J. Bank. Financ. 2011, 35, 2388-2406. [CrossRef]

4. Zhang, M.; Tong, L.; Su, J.; Cui, Z. Analyst coverage and corporate social performance: Evidence from China. Pac.-Basin Financ. J. 2015, 32, 76-94. [CrossRef]

5. Kim, B.; Pae, J.; Yoo, C. Business group and tunneling: Evidence from corporate charitable contributions by Korean companies. J. Bus. Ethics 2017, 154, 643-666.

6. Waddock, S.A.; Graves, S.B. The corporate social performance-financial performance link. Strateg. Manag. J. 1997, 18, 303-319. [CrossRef]

7. Amato, L.H.; Amato, C.H. The effects of firm size and industry on corporate giving. J. Bus. Ethics 2007, 72, 229-241. [CrossRef]

8. Barnea, A.; Rubin, A. Corporate social responsibility as a conflict between shareholders. J. Bus. Ethics 2010, 97, 71-86. [CrossRef]

9. Choi, J.; Wang, H. The promise of a managerial values approach to corporate philanthropy. J. Bus. Ethics 2007, 75, 345-359. [CrossRef]

10. Skapinker, M. Do corporate citizenship reports matter? Financ. Times 2011. Available online: http://ft.com/ content/d4fb10e8-c395-11e0-8d51-00144feabdc (accessed on 11 August 2011).

11. Hemingway, C.A.; Maclagan, P.W. Managers' personal values as drivers of corporate social responsibility. J. Bus. Ethics 2004, 50, 33-44. [CrossRef]

12. Chen, L.; Srinidhi, B.; Tsang, A.; Yu, W. Corporate Social Responsibility, Audit Fee and Audit Opinion; Working Paper; George Mason University: Fairfax, VA, USA, 2012.

13. Freidman, M. The social responsibility of business is to increase its profit. Corp. Ethics Corp. Gov. 2007. [CrossRef]

14. Jensen, M.C. Value maximization, stakeholder theory, and the corporate objective function. J. Appl. Corp. Financ. 2002, 22, 32-42. [CrossRef]

15. Brammer, S.; Millilington, A. Does it pay to be different? An analysis of the relationship between corporate social and financial performance. Strateg. Manag. J. 2008, 29, 1325-1343. [CrossRef]

16. Mishra, S.; Modi, S. Positive and negative corporate social responsibility, financial leverage, and idiosyncratic risk. J. Bus. Ethics 2013, 117, 431-448. [CrossRef]

17. El Ghoul, S.; Guedhami, O.; Park, K.; Kim, H. Corporate environmental responsibility and cost of capital: International evidence. J. Bus. Ethics 2018, 149, 335-361. [CrossRef]

18. Godfrey, P.C. The relationship between corporate philanthropy and shareholder wealth: A risk management perspective. Acad. Manag. Rev. 2005, 30, 777-798. [CrossRef]

19. Porter, M.; Kramer, M. Strategy \& Society. Harvard Bus. Rev. 2006, 84, 78-92.

20. Cheng, B.; Ioannou, I.; Serafeim, G. Corporate social responsibility and access to finance. Strateg. Manag. J. 2014, 35, 1-23. [CrossRef]

21. Jensen, M.C.; Meckling, W.H. Theory of the firm: Managerial behavior, agency costs and ownership structure. J. Financ. Econ. 1976, 3, 305-365. [CrossRef]

22. Barnett, M.L.; Salomon, R.M. Beyond dichotomy: The curvilinear relationship between social responsibility and financial performance. Strateg. Manag. J. 2006, 27, 1101-1122. [CrossRef]

23. Barnett, M.L.; Salomon, R.M. Does it pay to be really good? Addressing the shape of the relationship between social and financial performance. Strateg. Manag. J. 2012, 33, 1304-1320. [CrossRef]

24. Navarro, P. Why do corporations give to charity? J. Bus. 1988, 61, 65-93. [CrossRef]

25. Carroll, A.B. A three-dimensional conceptual model of corporate performance. Acad. Manag. Rev. 1979, 4, 497-505. [CrossRef]

26. Haley, U.C.V. Corporate contributions as managerial masques: Reframing corporate contributions as strategies to influence society. J. Manag. Stud. 1991, 28, 485-510. [CrossRef] 
27. Campbell, D.; Slack, R. The strategic use of corporate philanthropy: Building societies and demutualisation defences. Bus. Ethics 2007, 16, 326-343. [CrossRef]

28. Masulis, R.W.; Reza, S.W. Agency problems of corporate philanthropy. Rev. Financ. Stud. 2014, 28, 592-636. [CrossRef]

29. Werbel, J.D.; Carter, S.M. The CEO's influence on corporate foundation giving. J. Bus. Ethics 2002, 40, 47-60. [CrossRef]

30. Mellahi, K.; Frynas, J.G.; Sun, P.; Siegel, D. A review of the nonmarket strategy literature: Toward a multi-theoretical integration. J. Manag. 2016, 42, 143-173. [CrossRef]

31. Ashford, B.E.; Gibbs, D.W. The Double edge of organizational legitimation. Organ. Sci. 1990, 1, 177-194. [CrossRef]

32. Dowling, J.; Pfeffer, J. Organizational legitimacy: Social values and organizational behavior. Pac. Sociol. Rev. 1975, 18, 122-136. [CrossRef]

33. Chen, J.C.; Patten, D.M.; Roberts, R.W. Corporate charitable contributions: A corporate social performance or legitimacy strategy? J. Bus. Ethics 2008, 82, 131-144. [CrossRef]

34. Lev, B.; Petrovits, C.; Radhakrishnan, S. Is doing good good for you? How corporate charitable contributions enhance revenue growth. Strateg. Manag. J. 2010, 31, 182-200. [CrossRef]

35. Cahan, S.F.; Emanuel, D.; Sun, J. Are the reputations of the large accounting firms really international? Evidence from the Andersen-Enron affair. Audit. J. Pract. Theory 2009, 28, 199-226. [CrossRef]

36. DeFond, M.; Zhang, J. A review of archival auditing research. J. Account. Econ. 2014, 58, 275-326. [CrossRef]

37. Lee, S.C.; Rhee, M.; Yoon, J. Foreign monitoring and audit quality: Evidence from Korea. Sustainability 2018, 10, 3151. [CrossRef]

38. Choi, J.H.; Kim, J.B.; Zang, Y. Do abnormally high audit fees impair audit quality? Audit. J. Pract. Theory 2006, 29, 115-140. [CrossRef]

39. Choi, J.H.; Kim, J.B.; Liu, X.; Simunic, D.A. Audit pricing, legal liability regimes, and Big 4 premiums: Theory and cross-country evidence. Contemp. Account. Res. 2008, 25, 55-99. [CrossRef]

40. Chun, H.; Rhee, C. Analyst coverage and audit effort: Empirical approach to audit hour. J. Appl. Bus. Res. 2015, 31, 1-15. [CrossRef]

41. Caramanis, C.; Lennox, C. Audit effort and earnings management. J. Account. Econ. 2008, 45, 116-138. [CrossRef]

42. Lawrence, A.; Minutti-Meza, M.; Zhang, P. Can Big 4 versus Non-Big 4 differences in audit-quality proxies be attributed to client characteristics? Account. Rev. 2011, 86, 259-286. [CrossRef]

43. Li, F. Endogeneity in CEO power: A survey and experiment. Invest. Anal. J. 2016, 45, 149-162. [CrossRef]

44. Servaes, H.; Tamayo, A. The impact of corporate social responsibility on firm value: The role of consumer awareness. Manag. Sci. 2013, 59, 1045-1061. [CrossRef]

45. Giroud, X.; Mueller, H.M. Corporate governance, product market competition, and equity prices. J. Financ. 2011, 66, 563-600. [CrossRef]

46. Coles, J.L.; Li, F.; Wang, A.Y. Industry Tournament Incentives. Rev. Financ. Stud. 2018, 31, 1418-1459.

47. Core, J.; Cuay, W. The use of equity grants to manage optimal equity incentive levels. J. Account. Econ. 1999, 28, 151-184. [CrossRef]

48. Chung, K.; Jo, H. The impact of security analysts' monitoring and marketing functions on the market value of firms. J. Financ. Quant. Anal. 1996, 31, 493-512. [CrossRef]

(c) 2019 by the authors. Licensee MDPI, Basel, Switzerland. This article is an open access article distributed under the terms and conditions of the Creative Commons Attribution (CC BY) license (http:/ / creativecommons.org/licenses/by/4.0/). 